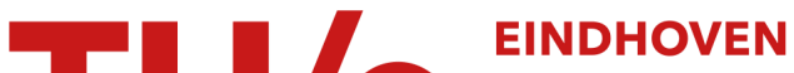 \\ UNIVERSITY OF \\ TECHNOLOGY
}

\section{Effect of olivine nano-silica additions on cement based system}

Citation for published version (APA):

Quercia Bianchi, G., \& Brouwers, H. J. H. (2015). Effect of olivine nano-silica additions on cement based system. In K. Sobolev, \& S. P. Shah (Eds.), Nanotechnology in Construction: Proceedings of NICOM5 (pp. 193-198).

Springer. https://doi.org/10.1007/978-3-319-17088-6_24

DOI:

10.1007/978-3-319-17088-6_24

Document status and date:

Published: 01/01/2015

Document Version:

Accepted manuscript including changes made at the peer-review stage

Please check the document version of this publication:

- A submitted manuscript is the version of the article upon submission and before peer-review. There can be important differences between the submitted version and the official published version of record. People interested in the research are advised to contact the author for the final version of the publication, or visit the $\mathrm{DOI}$ to the publisher's website.

- The final author version and the galley proof are versions of the publication after peer review.

- The final published version features the final layout of the paper including the volume, issue and page numbers.

Link to publication

\section{General rights}

Copyright and moral rights for the publications made accessible in the public portal are retained by the authors and/or other copyright owners and it is a condition of accessing publications that users recognise and abide by the legal requirements associated with these rights.

- Users may download and print one copy of any publication from the public portal for the purpose of private study or research.

- You may not further distribute the material or use it for any profit-making activity or commercial gain

- You may freely distribute the URL identifying the publication in the public portal.

If the publication is distributed under the terms of Article 25fa of the Dutch Copyright Act, indicated by the "Taverne" license above, please follow below link for the End User Agreement:

www.tue.nl/taverne

Take down policy

If you believe that this document breaches copyright please contact us at:

openaccess@tue.nl

providing details and we will investigate your claim. 


\title{
Effect of Olivine Nano-silica Additions on Cement Based Systems
}

\section{G. Quercia Bianchi and H.J.H. Brouwers}

\begin{abstract}
In this study, the influence of olivine nano-silica (OnS) additions in cement based systems has been addressed. The obtained results demonstrate that the addition of OnS (1.5-3.8 \% bwoc) increases the viscosity, yield point and hydration degree of the cementitious systems, mainly due to the increase of the total specific surface area of the mix. This holds also for the case when a fixed amount of $\mathrm{SP}$ is applied. Based on the performed analysis, it is concluded that the OnS acts as an accelerating and pozzolanic agent in concrete.
\end{abstract}

Keywords Nano-silica $\bullet$ Olivine $\bullet$ Cement $\bullet$ Mortar $\bullet$ Self-compacting concrete

\section{Introduction}

Olivine $(\mathrm{Mg}, \mathrm{Fe})_{2} \mathrm{SiO}_{4}$ is the fastest weathering silicate mineral dissolving easily in acids. During the dissolution in acid, the metallic ions $\left(\mathrm{Mg}^{2+}, \mathrm{Fe}^{2+}\right)$ are replaced by $\mathrm{H}^{+}$, yielding $\mathrm{Si}(\mathrm{OH})_{4}$ monomers and metallic ions in solution. After cleaning treatments an amorphous nano-silica is obtained [1]. The produced olivine nano-silica (OnS) has a specific surface area between 100 and $400 \mathrm{~m}^{2} / \mathrm{g}$, depending upon the dissolution and washing conditions. The size of the primary particles, which are agglomerated in clusters, ranges from 10 to $25 \mathrm{~nm}$ and the impurity content is below $5 \%$ by weight. Literature related with the application of $\mathrm{OnS}$ in cement based materials is scarce, only one research work performed by Justnes and Ostnor is available [2], thus, the effect of adding OnS in cement based systems has not been studied. Based on this the present research aims to elucidate the effects of $\mathrm{OnS}$ in the fresh and hardened cement pastes, standard mortars and self-compacting concretes with low $\mathrm{CO}_{2}$ footprint (eco-SCC).

\footnotetext{
G. Quercia Bianchi $(\bowtie)$

Eindhoven University of Technology, Eindhoven, The Netherlands

Trican Well Service Ltd, Calgary R\&D Centre, Calgary, AB, Canada

e-mail: g.quercia@tue.nl; gquercia@trican.ca

http://www.tue.nl; http://www.trican.ca
}

H.J.H. Brouwers

Eindhoven University of Technology, Eindhoven, The Netherlands 


\section{Materials and Experimental Methods}

Different olivine nano-silica cakes were used in dried or water dispersed form. The OnS used were prepared from different batches synthesized on pilot scale [3]. The cements used for the experiment were CEM I $52.5 \mathrm{~N}$, CEM I $52.5 \mathrm{R}$, CEM III/B 42.5 N LH/HS as classified by CEN EN 197-1 (2000). For the mortar test, standard sand (0-2 mm) was used according to CEN EN 196-1 (2000). In addition, commercial superplasticizers (SP) based on modified polycarboxylic ether (PCE) and naphthalene lignosulfonate ether (NLS) were used for the paste, mortar and concrete experiment. For the self-compacting concrete (SCC) experiments, fluvial aggregates in the fractions $0-8$ and $4-16 \mathrm{~mm}$ were used. In addition, fluvial sand in the fractions $0-4 \mathrm{~mm}$ was also used. Finally, a commercial fly ash was applied as supplementary cementitious material and filler. More details on the physicochemical characteristics of the materials used can be found in [3].

To study the effect of OnS and SP, rheological measurements and the mini spreadflow test were carried out to assess changes of the viscosity caused by the volumetric substitutions of cement $(0.5,1.5,3.0,4.5,7.0$ and $10 \%)$. The rheological tests were complemented with isothermal calorimetric measurements (cement pastes with w/c of 0.5; and with or without SP). Afterwards, compressive and flexural strength of standard mortars following the procedure established in EN 196-1 (2000) were carried out. Finally, optimized eco-SCC mixes were designed and evaluated as recommended by [4]. The reference mix design was based on a commercial SCC formulation for sewage pipes (Table 1 and Fig. 1a). For the optimized eco-SCC mixes with OnS (Fig. 1b), the mix design concepts described by [5, 6] were used. In total, four mixes were tested at the pilot scale, considering a volume of $1 \mathrm{~m}^{3}$. For this, two batches were cast with OnS cakes (DNOnS-14) produced from Norwegian olivine in The Netherlands and two batches with powder OnS produced from beneficiated dunites in Greece (PGOnS-1). One day before the pilot test, several water based dispersions with $10 \mathrm{wt} \%$ of OnS were prepared using both type (Dutch and Greek) nano-silica with an industrial rotor stator high energy mixer (3,000 rpm for $30 \mathrm{~min})$.

Table 1 eco-SCC mix designs using olivine nano-silica as cement (CEM I 52.5R) replacement

\begin{tabular}{l|l|c|c|c|c|c}
\hline Materials $\left(\mathrm{kg} / \mathrm{m}^{3}\right)$ & SCC- $_{\text {ref }}$ & SCC $_{\text {lab }}$ & SCC $_{-1 \mathrm{D}}$ & SCC- $_{2 \mathrm{D}}$ & SCC $_{-1 \mathrm{G}}$ & $\mathrm{SCC}_{-2 \mathrm{G}}$ \\
\hline DNOnS-14 (10 wt\% solid) & - & 122.0 & 122.0 & 122.0 & - & - \\
\hline PGOnS-1 (10 wt\% solid) & - & - & - & - & 122.0 & 122.0 \\
\hline CEM I 52.5 R & 95.0 & 38.0 & 34.0 & 42.0 & 32.0 & 38.0 \\
\hline CEM III/B 42.5 N LH/LS & 255.0 & 284.0 & 288.0 & 280.0 & 280.0 & 288.0 \\
\hline Fly-Ash & 160.0 & 173.0 & 172.0 & 174.0 & 172.0 & 172.0 \\
\hline Fluvial gravel 0-8 mm & 825.0 & 855.0 & 860.0 & 860.0 & 870.0 & 870.0 \\
\hline Fluvial gravel 4-16 mm & 1091.0 & 845.0 & 860.0 & 860.0 & 870.0 & 860.0 \\
\hline Water & 845.0 & 54.0 & 62.0 & 59.0 & 60.0 & 60 \\
\hline SP (\% bwob) & $3.5^{\mathrm{a}}$ & $6.5^{\mathrm{b}}$ & $5.0^{\mathrm{c}}$ & $5.2^{\mathrm{c}}$ & $4.0^{\mathrm{c}}$ & $3.5^{\mathrm{c}}$ \\
\hline w/b (measured after casting) & 0.43 & 0.43 & 0.45 & 0.44 & 0.46 & 0.44 \\
\hline
\end{tabular}

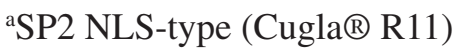

${ }^{b}$ SP3 PCE-type (Ha-Be Pantarhit ${ }^{\circ}$ RC 100)

'SP5 PCE-type (Ha-Be Pantarhit® PC 150) 
a

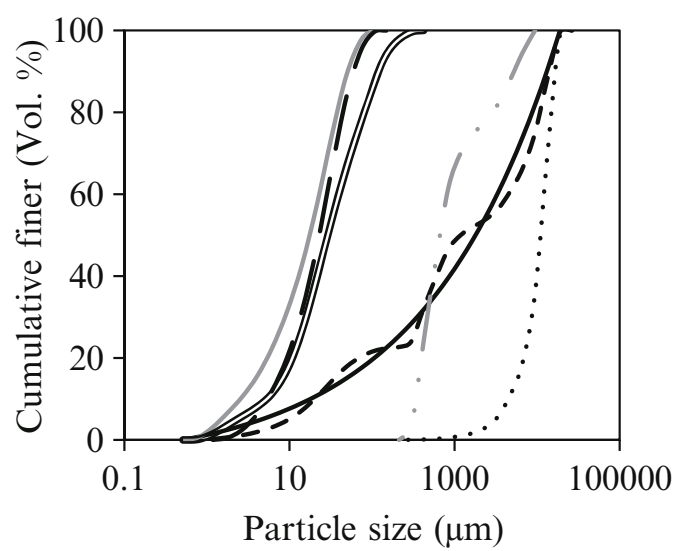

Particle size $(\mu \mathrm{m})$ b

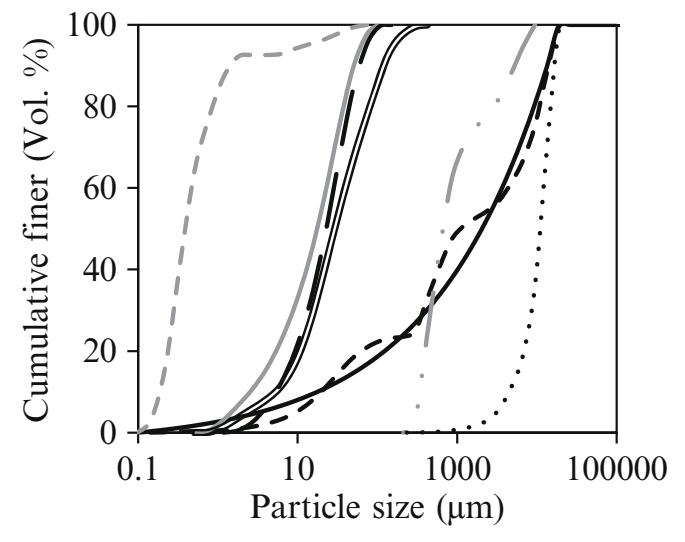

\begin{tabular}{|ll|}
\hline Target Function q=0.30 & --- Composed Mix \\
CEM I 52.5 R & - CEM III/B 42.5 LH/HS \\
Fly ash & --- DOnS-14 \\
Fluvial gravel $0-8 \mathrm{~mm}$ & $\cdots \cdots$. Fluvial gravel $4-16 \mathrm{~mm}$ \\
\hline
\end{tabular}

Fig. 1 PSD of the materials used, (a) reference eco-SCC with target function based on a $q=0.27$ $\left(D_{\min }=513 \mathrm{~nm}\right.$ and $D_{\max }=18.9 \mathrm{~mm},(\mathbf{b})$ initial eco-SCC (OnS) with target function based on a $\mathrm{q}=0.30\left(D_{\min }=65 \mathrm{~nm}\right.$ and $\left.D_{\max }=18.9 \mathrm{~mm}\right)$, dashed lines are the corresponding test mixes

\section{Results and Discussion}

\subsection{Effects on Cement Paste}

The obtained flow curves for all tested pastes are displayed in Fig. 2 the experimental data were fitted to the Herschel-Bulkley fluid model using the methodology recommended by [7]. This fluid model was selected as cement pastes show a shear thinning behavior.

The parameters determined by the rheological tests were compared with values obtained on mortar scale using the spread-flow test. It is demonstrated that the yield point of the paste is proportional to the spread flow and the total specific surface area [3]. The increase in the viscosity and in the yield point of the paste is a result of the increased specific surface are of the paste due to the addition of OnS. In this case it is demonstrated for a fix amount of SP that the workability of the cement paste decreased with increasing OnS content. In addition, it was found that the pastes presented a self-flowing characteristic when the cement paste possesses yield point values lower than $9 \mathrm{~Pa}$.

The obtained heat flow and total heat curves for all tested pastes are displayed in Fig. 3.

For the first system studied, where no SP was added (Fig. 3a), the heat flow curves are close to the reference sample. The main difference observed was in the so called dormant period, which is clearly reduced with increasing volumetric substitution of cement by OnS. In addition, a slight increase in the main hydration peak $\left(\mathrm{C}_{3} \mathrm{~S}\right.$ phase) was observed. This increase is produced by the higher reactivity of the OnS (pozzolanic behavior). In the second system studied (with SP) the retarding effect due to the addition of SP is still evident (Fig. 3b). Nevertheless, the accelerating 
a

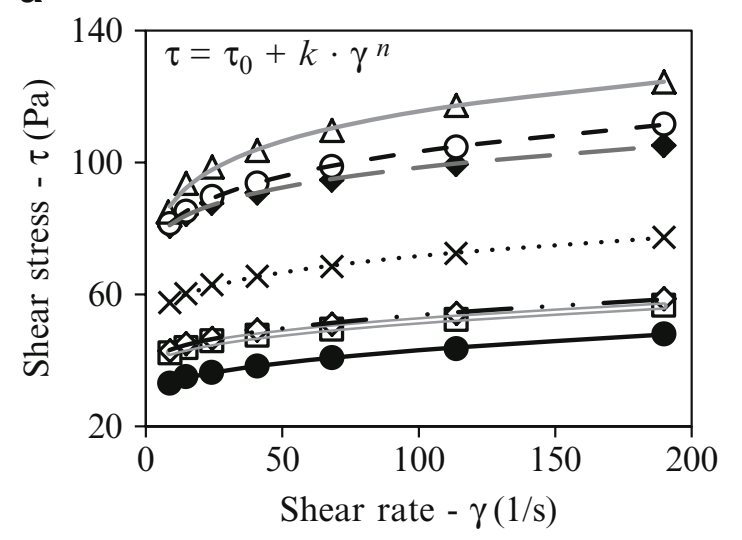

b

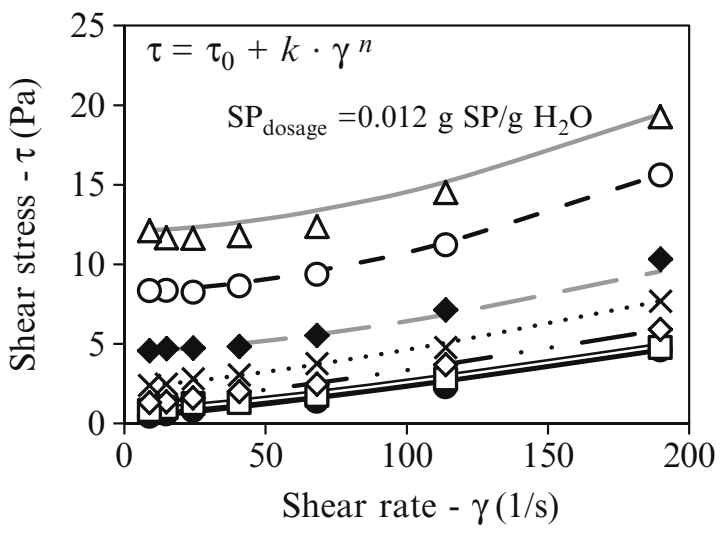

\begin{tabular}{llllllll}
$\bullet$ CEM I $52.5 \mathrm{~N}$ & $\square 0.5 \%$ & $\diamond 1.5 \%$ & $\times 3.0 \%$ & $\bullet 4.5 \%$ & $\circ 7.0 \%$ & $\Delta 10.0 \%$ \\
\hline
\end{tabular}

Fig. 2 Flow curves of the cement/OnS paste measured and adjusted to the Herschel-Bulkley fluid model: (a) without SP, (b) with fixed SP $(0.6 \%$ bwoc $)$

a

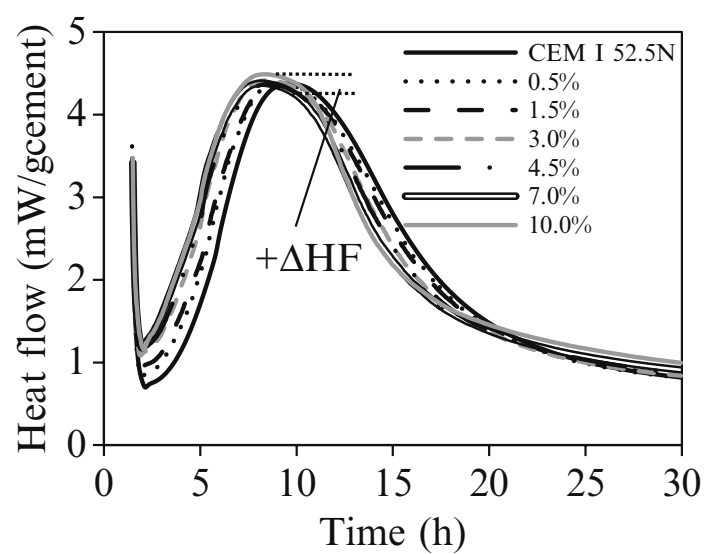

b

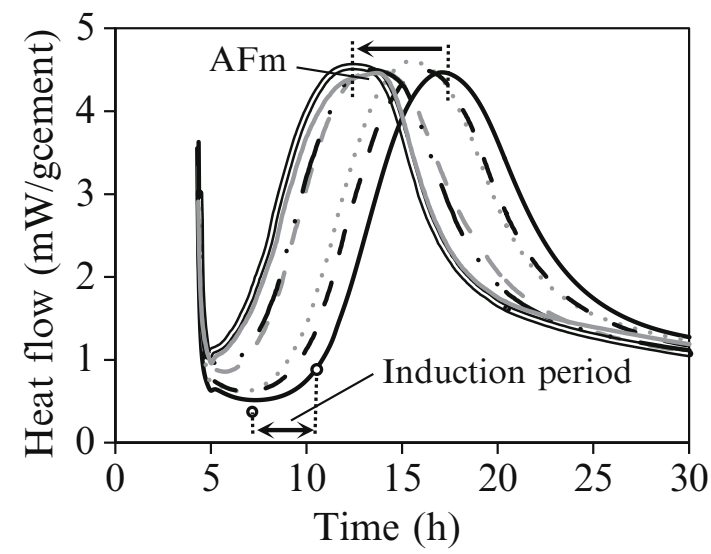

Fig. 3 Heat flow and total heat behaviour of cement/OnS paste: (a) without SP, (b) with fixed SP $(0.6 \%$ bwoc $)$

effect caused by the addition of OnS is also influential. In addition to this, an effect on the hydration of aluminates phases (secondary ettringite formation) is displayed for 10 vol\% substitution level.

\subsection{Effects on Standard Mortars}

The mechanical properties of mortars with different OnS additions and a fixed SP content are shown in Fig. 4. In general, almost all flexural strength values dropped when OnS was added. This fact is caused by the high agglomerated state of the OnS, which produced a more porous interparticle transition zone (ITZ). On the contrary, it is possible to observe in Fig. 4b that the compressive strength increases until a maximum that depends on the age of the samples. Once the maximum is reached the compressive strength dropped in comparison to the reference. The highest value at 28-day was obtained with $1.5 \mathrm{vol} \%$ of cement replacement by OnS. 
a

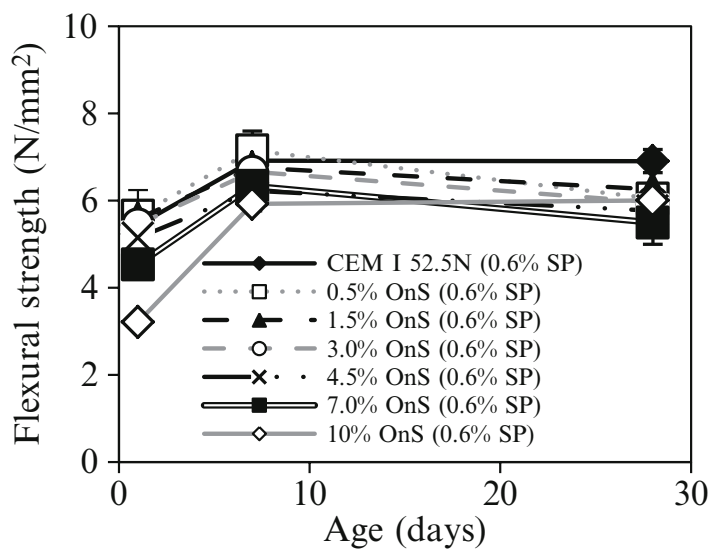

b

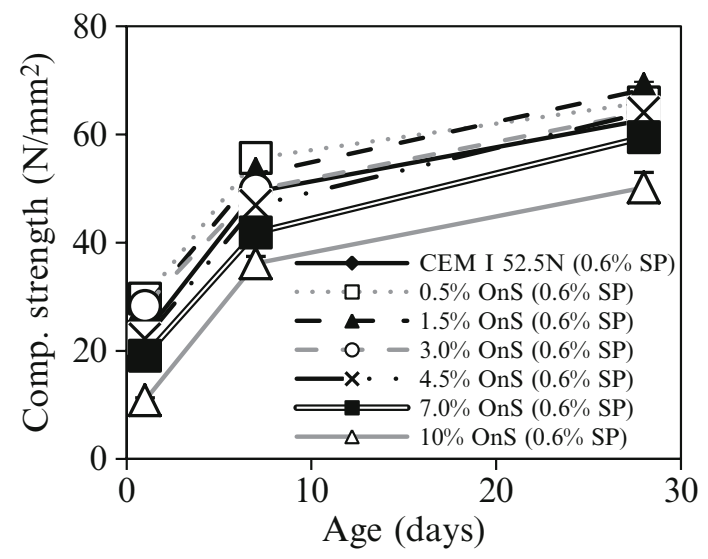

Fig. 4 Mechanical properties of mortars with different content of OnS (w/c $=0.5$ and $0.6 \% \mathrm{SP}$ ): (a) Flexural strength, (b) compressive strength

\subsection{Ecological Self-Compacting Concrete (Pilot Test)}

All resulting properties of the eco-SCC of the conducted pilot test tests are given in Table 2. As it can be seen in Table 2, only a lower slump-flow than the median value of $758 \mathrm{~mm}$ was obtained for the mix SCC- ${ }_{2 \mathrm{D}}$.

The values of the others test are within the production specifications of the company. Based on this observation, it is possible to conclude that the SCC mixes met the required slump flow set by the company. On the other hand, high V-funnel times can be related to a low deformability due to high paste viscosity, a high interparticle friction or a blockage of the funnel. Directly linked to this observation are the long $\mathrm{V}$-funnel values observed for $\mathrm{SCC}_{-2 \mathrm{G}}$ mix. Also, the higher $\mathrm{V}$-funnel time of mix $\mathrm{SCC}_{-1 \mathrm{G}}$ is the result of a lower amount of SP and water use. In the case of the mechanical properties, several observations can be made. Both type of OnS tests show lower 16-h compressive strength than the required minimum (Table 2). Despite the lower 16-h strength of the mixes, the final cast products (garden pals) were de-molded without problems or failures. The lower 16-h compressive strength is the result of the lower total binder content of the mix compared to the reference $(382 \mathrm{~kg} /$ $\mathrm{m}^{3}$ vs. $369 \mathrm{~kg} / \mathrm{m}^{3}$ ). On the contrary, the 28-days compressive strength values were higher than the minimum value of the reference $\left(55 \mathrm{~N} / \mathrm{mm}^{2}\right)$ for both SCC types with OnS (Table 2). The higher 28-day strength is a consequence of the improved fly ash and slag reactivity induced by the OnS particles, as it was confirmed by [3]. Taking into account the fresh and hardened properties combined with the final product quality, the pilot testing was qualified as a success by the concrete producer.

As a further analysis, an estimation of the $\mathrm{CO}_{2}$ foot-print of the resulted eco-SCC was performed using the equivalent $\mathrm{CO}_{2}$ foot-print of each compound taken from [3]. The analysis demonstrated that $\mathrm{CO}_{2}$ foot-print of an eco-SCC $\left(151 \mathrm{kgCO} / \mathrm{m}^{3}\right)$ is $18 \%$ lower than that the references SCC mix $\left(184 \mathrm{kgCO}_{2} / \mathrm{m}^{3}\right)$. Not only was the equivalent $\mathrm{CO}_{2}$ foot-print was reduced, it was also demonstrated that the use of $3.8 \%$ bwoc of OnS and the mix design tool developed by [5] can enhance the use of other binders (slag and fly ash). Thus, the total binder content in the SCC was reduced from 382 to $369 \mathrm{~kg} / \mathrm{m}^{3}$ (13 kg less). 
Table 2 Fresh and hardened properties of eco-SCC pilot test mixes

\begin{tabular}{l|l|l|l|l|l|l|l}
\hline Mix & S(mm) & $\begin{array}{l}\text { V-funnel } \\
\text { time (s) }\end{array}$ & $\begin{array}{l}\text { Stability } \\
\text { time }(\mathrm{s})\end{array}$ & $\begin{array}{l}\text { Blocking } \\
(\mathrm{mm})\end{array}$ & $\begin{array}{l}\text { 16-hs } \\
\text { C.S. } \\
\left(\mathrm{N} / \mathrm{mm}^{2}\right)\end{array}$ & $\begin{array}{l}\text { 7-day } \\
\text { C.S. } \\
\left(\mathrm{N} / \mathrm{mm}^{2}\right)\end{array}$ & $\begin{array}{l}\text { 28-day C.S. } \\
\left(\mathrm{N} / \mathrm{mm}^{2}\right)\end{array}$ \\
\hline Reference & $650-850$ & $12-13$ & $<3$ & $<10$ & $>8$ & $\mathrm{~N} / \mathrm{S}$ & $>55$ \\
\hline SCC- ${ }_{1 \mathrm{D}}$ & $810-810$ & $7.3-7.9$ & 1.8 & 5.3 & - & - & - \\
\hline SCC- $_{2 \mathrm{D}}$ & $580-600$ & $11.1-12.4$ & 2.5 & 5.0 & 7.13 & 39.7 & 68.3 \\
\hline${\text { SCC- }{ }_{1 \mathrm{G}}}^{\text {SCC- }}$ & $750-790$ & $13.1-14.1$ & 3.9 & 5.8 & - & - & - \\
\hline
\end{tabular}

\section{Conclusions}

In this study, the influence of olivine nano-silica (OnS) additions in cement based systems has been addressed. The tests results demonstrated that the addition of OnS increases the viscosity and the yield point of the cement system. This holds also for the case in which commercial superplasticizers are applied. The increase in the viscosity and the yield point of the paste is the result of the increased specific surface area of the paste. Based on the isothermal calorimetric measurements and the analysis performed, it is possible to conclude that the OnS acts as an accelerating agent in concrete. The experiments also demonstrated that the possible optimum replacement level of OnS would be between 1.5 and $4.5 \%$ by vol. to obtain a concrete with reduced $\mathrm{CO}_{2}$ foot-print.

\section{References}

1. Lazaro, A., Brouwers, H. J. H., Quercia, G., \& Geus, J. W. (2012). The properties of amorphous nano-silica synthesized by the dissolution of olivine. Chemical Engineering Journal, 211-212, $112-121$.

2. Justnes, H., \& Ostnor, T. (2001). Pozzolanic, amorphous silica produced from the mineral Olivine. In V. M. Malhotra (Eds.), Proceedings of the 7th CANMET/ACI international conference on Fly ash, Silica fume, Slag, and Natural pozzolans in Concrete (Vol. II), Chennai. American Concrete Institute (ACI) Special Publication 199, 769-781 (DOI 10.14359/10547).

3. Quercia, G. (2014). Application of nano-silica in concrete (pp. 1-328). PhD dissertation, Eindhoven University of Technology, Eindhoven.

4. EFNARC. (2005). Specification and guidelines for Self Compacting Concrete-SCC. Report, European Federation of Producers and Contractors of Specialist Products for Structures, Surrey.

5. Hüsken, G., \& Brouwers, H. J. H. (2008). A new mix design concept for earth-moist concrete: A theoretical and experimental study. Cement and Concrete Research, 38, 1246-1259.

6. Hunger, M. (2010). An integral design concept for ecological self-compacting concrete (pp. 1-260). PhD thesis, Eindhoven University of Technology, Eindhoven.

7. Klotz, J. A., \& Brigham, W. E. (1998). To determine Herschel-Bulkley coefficients. Journal of Petroleum Technology, 50, 80-81. 